\title{
IAMJ
}

INTERNATIONAL

AYURVEDIC

MEDICAL JOURNAL

\section{CLINICAL EVALUATION OF BHRINGRAJ CAPSULE AND OIL ALONG WITH NASYA IN THE MANAGEMENT OF KHALITYA W.S.R TO HAIR-FALL}

\author{
Nishu Raina \\ Assistant Professor Kayachikitsa, DAC, Jalandhar, Punjab, India \\ Corresponding Author: nishu.raina2010@gmail.com
}

https://doi.org/10.46607/iamj03p5062021

(Published online: September 2021)

Open Access

(C) International Ayurvedic Medical Journal, India 2021

Article Received: 05/08/2021 - Peer Reviewed: 23/08/2021 - Accepted for Publication: 24/08/2021

Check for updates

\begin{abstract}
Hair shedding is part of a natural balance, where some hairs fall out while others grow in. When the balance between hair production and shedding is interrupted that is what we called, hair loss. It can be the result of heredity, hormonal changes, medical conditions or a normal part of ageing. Anyone can lose hair on their head, but it's more common in men. when we talk about Baldness, it typically refers to excessive hair loss from your scalp. Hereditary hair loss with age is the most common cause of baldness. As far as Ayurveda is considered, it is described there by the name of Khalitya Roga under the heading of Kshudra Roga or Shiro Roga. whensoever we talk about it, it is a completely progressing disorder which is found mostly in all those persons who are indulged in sedentary ways of life, stressinduced hectic schedules along with indiscriminate dietary habits which in turn can result in any disturbance in the body which in turn can directly reflect in the form of hair loss. In this article, we will see how We can reduce \& manage this rising problem of hair fall through Bhringraj capsule and oil along with Nasya. For this study, 31 patients with diffuse hair loss were instructed to gently massage the Bhringraj Taila daily onto the entire area of the scalp. Response to the therapy was evaluated at the end of four weeks. Evaluation of efficacy was done on the basis of improvement in clinical symptoms like hair fall, dandruff, itching, dryness etc. The present study thus showed a significant reduction in hair fall, dandruff, itching etc. $(p<0.001)$. There were no adverse reactions, either reported or observed during the entire study period and overall compliance to the treatment was excellent. Finally at last, it was concluded that Bhringraj Taila was found to be effective in alleviating Khalitya along with a significant effect on associated
\end{abstract}

Keywords: Khalitya, indralopa, hair oil, Nasya, Bhringraj 


\section{INTRODUCTION}

Hair fall has been described in almost all the Ayurvedic literature as Khalitya ${ }^{l}$. It has been included in Shiroroga by Acharya Charaka \& Ashtanga hridayakar. This inclusion has been done based on Shtana (location) of diseases and similarity of etiopathogenesis of diseases. It is mentioned in Ashtanghridaya that nine diseases occurring on the outer part of the head over the scalp should be called shiroroga. Sushrut Samhita, Ashtanga Samgraha, Yoga Ratnakar and Madhav Nidan, has included Khalitya diseases under Kshudra Roga. This inclusion in Kshudra Roga is due to the mildness of the disease. These diseases are not life-threatening and are of less severity in comparison to other major diseases. Pathogenesis of Khalitya stated by Acharya Vagbhata states that pitta present in hair follicles associated with Vata causes falling of hairs, afterwards Kapha and Rakta Dosha in that area block the hair follicle to prevent new hair growth ${ }^{2}$. Darunaka is when the ground of hairs becomes hard, dry and rough due to aggravation of Vata and Kapha Dosha in scalp ${ }^{3}$. There is also falling of hairs, dryness itching and small cracks on the skin of scalp ${ }^{4}$

\section{MATERIAL AND METHODS}

Ayurveda mentioned that the human body is made up of main seven Dhatus (body elements) viz. Rasa, Rakta, Mansa, Meda, Asthi, Majja and Sukra. The majority of Acharyas believe that the production of later Dhatu occurs from former dhatu by the function of their respective Agni i.e. the Rasagni turns the Ahara Rasa into Rasa Dhatu then Raktagni converts part of Rasa Dhatu in Rakta and so on. Along with the production of later Dhatu, there is side by side production of Upadhatu \& Mala of former Dhatu. During this process of production of Dhatus when the metabolism of Asthi Dhatu occur by its Agni \& Majja Dhatu emerges from the Sara part and at the same time hair of scalp \& body and nails form as Mala. Gradual falling of hair is known as Khalitya. When pitta combines with vata or kapha dosha to destroy the hair, it is called khalitya. According to acharya Sharngadhar, Scalp and body hair are the updhatu of Majja dhatu ${ }^{5}$. Among all the garbhaj bhava (factors for the development of foetus), hair is pitraj bhava means structure, colour and quantity of progeny are dependent on the paternal side ${ }^{6}$. Hair is made up of mainly parthiva mahabhoota (earth element). Hair formation starts during the sixth month of intrauterine life ${ }^{7}$. According to modern science, Hair can be defined as a modified epithelial structure formed as a result of keratinisation of germination cell ${ }^{8}$. Hair is an epidermal appendage that lies with the dermis. Every hair emerges from the hair follicles which resembles a slim pocket insides epidermis. Hair is present in every discipline of the epidermis beside the palm, sole and lips. Hair development undergoes a repetitive cycle. In the scalp, the hair growth cycle has three essential phases: Anagen, Catagen and Telogen. The anagen segment is a progress phase that most commonly lasts 3-5 years. One a healthy scalp, there are roughly 100000 hair \& $90 \%$ of the follicles are consistently in the anagen segment of hair development. The Catagen stage follows this phase when the follicles begin to end up dormant which lasts for 2-3 weeks. The telogen stage is a dormant stage or resting interval that lasts 34 months. When this stage ends, hair falls out. That hair follicle then returns to the anagen stage \& new hair begins to develop. In this way, the hair growth cycle continues. 50-60 hairs are lost per day in the normal hair growth cycle.

Causes of Khalitya Roga $a^{9}$ Due to usna guna of pitta dosha $\neg$ individual of pitta Prakriti starts hair fall and greying of hair earlier than individuals of other doshas Prakriti.

Approach to Patient of Khalitya - Hair fall can be manifested as a primary disease (as an independent disease) as well as secondary to other disorders or can be present as a symptom of many diseases. Because of its variable etiopathogenesis, we need a careful approach to the patients for proper diagnosis and treatment of hair fall (khalitya). Proper history should be taken including all the criteria like past medical history, family history and personal history along with other general \& systemic examinations. The scalp \& body should be carefully examined to detect any abnormality in the skin. 
The total duration of the study was 28 days

Ingredient of bhringraj taila (Siddha Yoga Sangraha- S.Y.S)

\begin{tabular}{|l|l|l|l|}
\hline Ingredient & Latin name/English name & Form used & Ratio \\
\hline $\begin{array}{l}\text { Bhringaraja } \\
\text { Amla juice }\end{array}$ & $\begin{array}{l}\text { Eclipta alba } \\
\text { Linn. Hassk. }\end{array}$ & $\begin{array}{l}\text { Expressed } \\
\text { Juice (whole plant) }\end{array}$ & $\begin{array}{l}\text { 4 Parts } \\
\text { 1 Part }\end{array}$ \\
\hline Brahmi juice & & & 1 part \\
\hline BASE OIL- Til Taila & sesame oil & 2 parts \\
\hline HERBS FOR KALKA (Paste) & & & \\
\hline Haritki & Terminalia Chebula & 0.4 part \\
\hline Bibhitaki & Terminalia Bellirica & 0.4 part \\
\hline Amla & Emblica Officinalis & 0.4 part \\
\hline Nagarmotha & Cyprus Rotundus & 0.4 part \\
\hline Kachur & Curcuma zedoaria & 0.4 part \\
\hline Lodhra & Symplocos Racemosa & 0.4 part \\
\hline Manjistha & Rubia Cordifolia & 0.4 part \\
\hline Babchi & Psoralea Corylifolia & 0.4 part \\
\hline Lal chandan & Pterocarpus santalinus & & 0.4 part \\
\hline Padmak & Prunus cerasoides & & 0.4 part \\
\hline Anantamul & hemidesmus indicus & & 0.4 part \\
\hline Mehndi & lawsonia inermis & 0.4 part \\
\hline Priyangu & callicarpa macrophylla & & 0.4 part \\
\hline Mulethi & glycyrrhiza glabra & 0.4 part \\
\hline Jatamansi & nardostachys jatamansi & & 0.4 part \\
\hline Kuth & saussurea lappa & 0.4 part \\
\hline Mandur & - & & 0.4 part \\
\hline
\end{tabular}

\section{Medication Intervention}

Bhringraj Taila was provided to each of the patients and instructed to apply every alternate day on the scalp [6 $\mathrm{ml} /$ application]. Instructions were also given to massage the scalp gently for $10 \mathrm{~min}$ after the application of hair oil. The patients were advised to use the oil in the morning. On the day of hair wash, they were advised to apply the oil after the bath. The total quantity of the oil was left to the usage practice of each patient. The total duration of the study was 28 days. Each patient was reviewed in the OPD once a week over the study period of 28 days. All patients were followed for 2 weeks to check their compliance with the treatment. Clinical assessment of scalp lesions was done objectively (by a doctor) and also subjectively (by the patient). Thorough scalp examination was done after completion of 1 week and at the end of the study.
The severity of the dandruff symptoms, itching, white scales and hair fall was recorded.

Assessment of Chief Complaints: -

Subjective assessment for the improvement in the severity of symptoms viz. dandruff, itching, dryness, stiffness of hair, perspiration and burning sensation in scalp was scored as,
1) Absent -0,
2) Mild - 1,
3) Moderate - 2 and
4) Severe -3 .

For the presence of hair fall, the assessment criteria were,

1) No Hair Fall - 0,

2) Hair fall during combing the wet hair or after oiling the hair \& combing -1 ,

3) Hair fall during washing the hair and normal combing -2 and 
4) Hair falls without combing -3 .

Srotodushti was assessed as per the signs and symptoms mentioned by Acharya Charaka and incorporated in the clinical proforma. The predefined primary efficacy endpoints were a rapid clinical improvement and symptomatic control of the clinical condition. The predefined secondary safety endpoints for short- and long-term were assessed by incidence of adverse events and patient compliance to the therapy. Statistical Analysis: - Statistical analysis was done according to intention-to-treat principles. The changes in various parameters from baseline values and the values after 4 weeks were evaluated by "Paired ' $t$ ' Test". The minimum level of significance was fixed at a $99 \%$ confidence limit and a 2 -sided p-value of several females was seen. This may be due to the short sample size. But the gravity of the problem in both the sexes cannot be denied.

1) More number of patients enrolled for the present trial were between the age group of $15-30 \mathrm{yrs}$ $(64.52 \%)$.

2) Malnutrition, faulty dietary habits and stress are the main problems faced by this particular age group. These factors directly contribute to the Rasavaha Sroto Dushti leading to hair fall.

3) Further, Lavana and Katu Rasa dominated the dietary habits of maximum patients. Premature greying of hair and hair fall is attributed to excess consumption of Lavana Rasa (Charaka Samhita).

4) Acharya Charaka has mentioned that people of Saurashtra are habituated to excessive consumption of salty diet and suffer from Khalitya, Palitya, Vali etc. (Charaka Samhita)

5) As far as the vitiation of Srotas is concerned, Rasavaha Dushti was predominant followed by Asthivaha and Swedovaha. It is easily reflected from the pattern of lifestyle followed in the particular area (Saurashtra).

6) Hair is said to be the Upadhatu (Sharangadhara Samhita) as well as Mala (Charaka Samhita) of
Asthi Dhatu. Hair fall is mentioned as one of the symptoms of Asthi Kshaya (Charaka Samhita).

7) Therefore, these findings support the involvement of particular Srotas in the aetiology of hair fall. Hair fall was found in all patients followed by dryness and stiffness.

8) Dandruff and itching were also found in $83.87 \%$ of patients.

9) Epidemiological data shows that dandruff is the leading cause of itching and hair fall (Diana DZ. et al.).

10) Dandruff mostly occurs after puberty (between the ages of 20 and 30 years) and affects males more than females (Shimer A. et al.)

11) In the present study maximum patients were from a particular age group and were males. Dandruff or Pityriasis simplex/ovale is often associated with other types of fungal infections (Gemmer CM. et al.).

12) Associated complaints like local fungal infection (near neck, behind ears etc.), migraine, depression, diabetes and allergic conjunctivitis were also found in few patients. Migraine and depression indicate "Chintyanaam Atichintanaata". This is the mental etiological factor responsible for Rasavaha Sroto Dushti (Charaka Samhita).

As far as the effect of hair oil is concerned on chief complaints, maximum relief was found in itching followed by dryness, stiffness, and hair fall. On applying student's ' $t$ ' test for the results obtained, highly significant result on all cardinal symptoms was seen. Understanding the mode of action of Bhringraj Taila is a complex phenomenon. It may be due to the synergistic action of its constituent ingredients. Therefore, they are analyzed individually for the reason of their inclusion in this particular formulation. Bhringaraja has antibacterial (Karthikumar S. et al.) [20] and hair stabilizing properties (Thorat R. et al.) [31] I 
Effect of Bhringraj Taila on the chief and associated complaints.

\begin{tabular}{|l|l|l|l|}
\hline Symptom & Mean \pm SEM & $\%$ Change & 't' value \\
\hline Hair fall & $2.19 \pm 0.13$ & 87.17 & $17.37^{*}$ \\
\hline Dandruff & $1.65 \pm 0.17$ & 83.60 & $09.64^{*}$ \\
\hline Itching & $1.58 \pm 0.18$ & 98.00 & $08.58^{*}$ \\
\hline Kesha Rukshatva (dryness) & $1.77 \pm 0.15$ & 88.71 & $12.28^{*}$ \\
\hline Kesha Kathinya (hardness) & $1.71 \pm 0.16$ & 88.33 & $10.56^{*}$ \\
\hline Keshabhomi Sweda (sweating) & $1.07 \pm 0.15$ & 78.57 & $07.28^{*}$ \\
\hline Keshabhomi Daha (burning) & $0.87 \pm 0.15$ & 84.37 & 06.02 \\
\hline
\end{tabular}

$* \mathrm{P}<0.0801$ (highly significant)

\section{Effect of bhringraj Taila on hair fall:-}

Terminalia chebula acts as a good source of antidandruff agents. Terminalia bellerica showed dose-dependent antidandruff activity. The aqueous extract of Terminalia bellerica exhibited a strong inhibition of $28 \mathrm{~mm}$ at $25 \%$ concentration whereas the ethanolic extract showed a $25 \mathrm{~mm}$ inhibition zone in the same concentration (Balakrishnan KP. et al.). Tannins present in Triphala possess the property of binding to proteins and even precipitating them. They even react with bacterial cell walls; counteract fungi by interfering with surface proteins. Due to slightly astringent taste, their use tightens the surface of the scalp and hair follicles, strengthening the follicles' grasp on each hair (Bele AA. et al.). Similarly, on phytochemical screening, antibacterial properties of leaves of Pongamia pinnata Linn. (Fabaceae) from India has been demonstrated (Arote SR. et al.). Petroleum ether extract of leaves and flowers of Hibiscus rosa-sinensis was evaluated for its potential on hair growth by in vivo and in vitro methods. In vivo, $1 \%$ extract of leaves and flowers in liquid paraffin was applied topically over the shaved skin of albino rats and monitored and assessed for 30 days. In vitro, the hair follicles from albino rat neonates were isolated and cultured in DMEM supplemented with $0.01 \mathrm{mg} / \mathrm{ml}$ petroleum ether extract of leaves and flowers. From the study, it was concluded that the leaf extract, when compared to flower extract, exhibits more potency on hair growth (Adhirajan N. et al.).

Nasya (nasal drop) - Everybody should t take the nasal drop of "Anu tail" every year during the rainy, autumn and spring season when the sky is free from clouds.
Along with many other benefits, it prevents hair fall and also accelerates the growth of hair ${ }^{10}$. Nasya nourishes the srotas present above the clavicle including the hair follicles which strengthen the hair and reduce falling. Snana (taking bath) - Acharya Sushruta mention that the head and hair should not be washed with warm water or with very cold water ${ }^{11}$. Pouring warm water overhead reduces the strength of hair \& eyes.

\section{DISCUSSION}

Khalitya is a common but very challenging and capricious disease of the world population and can have a profound effect on physical and emotional state. Viruddha Ahara, Pitta Vardhak Ahara Vihara, Abhishyandi Ahara, a sedentary lifestyle increases Pitta and Vata which leads to Khalitya. Ayurvedic management for Khalitya is Abhyang, Shodhan, Lepan, Nasya, Rasayana therapies. Abhyang Chikitsa, especially with oil is best for Vata Dosha Shaman. Abhyang of oil, which is prepared by Kapha, Pitta and Vatahar Dravyas helps in Vata Shaman along with Pitta and Kapha Shaman. Shirolepan Karma, which is performed by Vatahar, Pittahar and Kaphahar Dravyas normalize Vata, Pitta and Kapha Dosha accordingly. Shodhana and Nasya Karma is a specialised therapy of Ayurveda. Shodhana is a procedure that takes out the doshas from the nearest route of its vitiation. Rasayana therapy has immunemodulators, antioxidant properties and rejuvenating action which is very beneficial for the hair fall caused by any chronic illness, premature ageing or nutrition deficiency. 


\section{CONCLUSION}

Khalitya is a wicked disease that needs proper management. Some minor changes in lifestyle and dietary habits can prevent hair fall. Proper hair care life oiling, washing, protection from external factors like environment, chemicals, heating etc is important for preventing hair fall and keeping them healthy. Before starting treatment of hair fall, the physician should identify the cause and the first treatment should be Nidanparivarjana or management of that cause. Then after other therapies like Abhyang, Lepana, Shodhan, Nasya, Rasayana should be prescribed accordingly. In this way, we can treat the Khalitya Roga or hair fall effectively.

\section{REFERENCES}

1. D Williamson, M Gonzalez, AY Finlay. The effect of hair loss on quality of life. European Academy of Dermatology and Venereology. 2001 15, 137-139

2. Vagbhat, Astanga Hridaya, English translation, vol. III, Prof. K. R. Srikantha Murthy, Uttara sthana, shiroroga vigyaniya adhyaya (23;24,25). Varanasi: Chowkhambha Sanskrit Series Office; 1997. p. 222

3. Vagbhat, Astanga Hridaya, English translation, vol. III, Prof. K. R. Srikantha Murthy, Uttara sthana, shiroroga vigyaniya adhyaya $(23 ; 25,26)$. Varanasi: Chowkhambha Sanskrit Series Office; 1997. p. 222

4. Agnivesha, Charaka Samhita, English translation, vol. II, Dr Ram Karan Sharma and Vaidya Bhagwan Dash, Vimansthan, Rogabhishagjiteeya adhyaya (8;97). Varanasi: Chaukhambha Sanskrit Series office; 1985. p. 264

5. Agnivesha, Charaka Samhita English translation, vol. IV, Chikitsasthan, grihanidoshachikitsa adhyaya (15; 19). Varanasi: Chaukhambha Sanskrit Series office; 2009. p.15.

6. Sharngadhara, Sharngadhara Samhita, Prof. K. R. Srikanta Murthy, Prathamakhand, kalaadikakhyana adhyay (5:15). Varanasi: Chaukhambha orientalia; 2001. p.21.

7. Agnivesha, Charaka Samhita, English translation, vol. II, Dr. Ram Karan Sharma and Vaidya Bhagwan Dash, Sharirasthan, khuddikagarbhavakrantisharira adhyaya (3;7). Varanasi: Chaukhambha Sanskrit Series office; 1985. p.371.

8. Vagbhat, Astangasamgraha, Sasilekha Sanskrit commentary by Indu, Prof. Jyotir Mitra, Sharirasthan, garbhavakranti adhyaya (2;23). Varanasi: Chaukhambha Krishnadas Academy; 2008. p.278. Princy Purwar et.al. Khalitya (Hair Fall) Management - Ayurvedic Perspective International Journal of Health Sciences \& Research (www.ijhsr.org) 260 Vol.9; Issue: 4; April 2019

9. Gerard Tortora and Bryan Derrickson: Principles of Anatomy and Physiology, John Wiley and Sons, Hoboken, Volume 2 Page no - 155-157

10. Agnivesha, Charaka Samhita, English translation, vol. I, Dr Ram Karan Sharma and Vaidya Bhagwan Dash, Sutrasthan, Matrashiteeyadhyaya (5;81). Varanasi: Chowkhambha Sanskrit Series office; 2006. p. 124.

11. Agnivesha, Charaka Samhita, English translation, vol. I, Dr Ram Karan Sharma and Vaidya Bhagwan Dash, Sutrasthan, Matrashiteeyadhyaya (5;57-58). Varanasi: Chowkhambha Sanskrit Series office; 2006. p. 120.

12. Sushruta, Sushruta Samhita, English translation, vol. II, Kaviraj Kunjalal Bhishagratna, Chikitsasthan, Anagatabadhapratishedhaneeyadhyaya (24;56). Varanasi: Chowkhambha Sanskrit Series Office; 2002.p. 570.

\section{Source of Support: Nil \\ Conflict of Interest: None Declared}

How to cite this URL: Nishu Raina: Clinical Evaluation Of Bhringraj Capsule And Oil Along With Nasya In The Management Of Khalitya W.S.R To Hair-Fall. International Ayurvedic Medical Journal \{online\} 2021 \{cited September 2021\} Available from: http://www.iamj.in/posts/images/upload/3076_3081.pdf 